\title{
Folate Receptor Targeted Epothilone BMS753493
}

National Cancer Institute

\section{Source}

National Cancer Institute. Folate Receptor Targeted Epothilone BMS753493. NCI

Thesaurus. Code C71524.

A folate receptor-targeting antimitotic agent with potential antineoplastic activity. Folate receptor-targeted epothilone BMS753493 contains an epothilone moiety linked to a single folate molecule. Mediated through the folate moiety, this agent delivers the antimitotic epothilone component into cells expressing folic acid receptors, frequently upregulated in many types of tumor cells. After ligand-receptor internalization, the epothilone moiety induces microtubule polymerization and stabilizes microtubules against depolymerization, resulting in the inhibition of mitosis and cellular proliferation. 